11. Кримінальний процесуальний кодекс України. Науково-практичний коментар : у 2 т. Т. 1 / О. М. Бандурка та ін. Харків : Право, 2012. 768 с.

12. Міліціанов Р. В. Класифікація конституційних засад судочинства в Україні. Науковий вісник Херсонського державного університету. Серія «Юридичні науки». 2014. Вип. 5. T. 1. С. 107-111.

13. Притика Ю. Д. Зміст та класифікація принципів медіації. Бюлетень Міністерства юстиичї України. 2010. № 10. С. 86-92.

14.Про судоустрій і статус суддів: Закон України від 02.06.2016 № 1402-VIII. URL: https://zakon.rada.gov.ua/laws/card/1402-19.

15. Теліпко В. Е. науково-практичний коментар Конституції України / За ред. Мусіяки В. Л. Київ : Центр учбової літератури, 2011. 544 с.

16. Цивільний процесуальний кодекс України від 18.03.2004 № 1618-IV URL: https://zakon.rada.gov.ua/laws/card/1618-15.

КОРНІЕНКО М. В., доктор юридичних наук, професор, перший проректор (Дніпровський гуманітарний університет)

СокоЛ Д. О., студент II курсу магістратури юридичного факультету (Дніпровський гуманітарний університет)

УДК 343.2

DOI https://doi.org/10.32842/2078-3736-2019-6-1-6

\title{
ДЕЯКІ ПИТАННЯ НОРМАТИВНО-ПРАВОВОЇ РЕГЛАМЕНТАЦЇ̈ ПРАВА НА ВІЛЬНИЙ ДОСТУП ДО ВОГНЕПАЛЬНОЇ ЗБРОЇ
}

У статті досліджуються окремі проблемні питання нормативно-правової регламентації права на вільний доступ до вогнепальної зброї, з'ясовується його природа й місце у вітчизняному законодавстві. Адже проблеми забезпечення різноманітних прав і свобод громадян України на перехідному етапі від тоталітарного російського впливу до засад правової європейської держави, в умовах російсько-терористичної агресії вимагають по-новому поглянути на засади та правовий інструментарій обігу й застосування зброї в Україні. Провідне місце в системі правових норм, за допомогою яких здійснюється забезпечення обігу й застосування зброї, відведено нормам адміністративного та кримінального права, що регулюють юридичний режим обігу зброї, порядок її придбання, зберігання, носіння i, як крайній засіб, - застосування 3 метою захисту життя та здоров’я громадян, забезпечення територіальної цілісності України від загрози з боку російсько-терористичних військових формувань. Значної актуальності цьому дослідженню додає проведення Збройними Силами України,

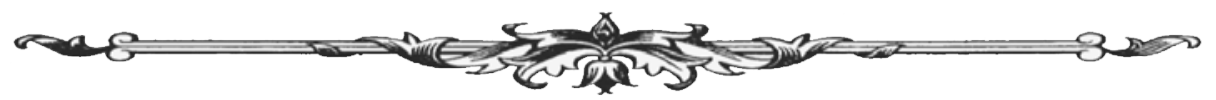


іншими збройними формуваннями та добровольчими батальйонами оборонної операції на сході Україні. Одночасно військові дії призводять до значного нелегального обігу зброї. Необлікована зброя стає джерелом скоєння злочинів і нещасних випадків із летальними наслідками. Тим самим проблема легалізації обігу зброї та вдосконалення правових положень її застосування $\epsilon$ надзвичайно актуальною для вітчизняного суспільства. Тож у дослідженні аналізуються особливості нормативно-правового регулювання правил придбання громадянами спеціальних засобів. У висновках зазначається про необхідність удосконалення законодавчих положень, які регулюють обіг зброї, та пропонується практичний механізм реалізації права на вільний доступ до зброї в Україні.

Ключові слова: зброя, боєприпаси, обіг зброї, спеціальні засоби, зберігання та використання зброї, предмет самозахисту, вільний доступ до зброї, вільне володіння зброєю.

The article examines some of the problematic issues of the legal regulation of the right to free access to firearms, its nature and place in domestic law is clarified. Indeed, the problems of ensuring various rights and freedoms of citizens of Ukraine at the transitional stage from totalitarian Russian influence to the foundations of a legal European state, in the context of Russian-terrorist aggression, require a fresh look at the principles and legal tools of handling and using weapons in Ukraine. The leading place in the system of legal norms by which the circulation and use of weapons is ensured is allocated to the norms of administrative and criminal law governing the legal regime of the circulation of weapons, the procedure for their acquisition, storage, carrying and, as a last resort, application to protect life and health citizens, ensuring the territorial integrity of Ukraine from threats from Russian-terrorist military units. This research is given significant relevance by the Armed Forces of Ukraine, other armed groups and volunteer battalions of the defensive operation in eastern Ukraine. At the same time, hostilities lead to a significant increase in illegal arms trafficking. Unaccounted weapons become a source of committing crimes and fatal accidents. Thus, the problem of legalizing the circulation of weapons and improving the legal provisions for its use is extremely relevant for domestic society. Therefore, the study analyzes the peculiarities of legal regulation of the rules for the acquisition of special funds by citizens. The conclusions note the need to improve the legislative provisions governing the circulation of weapons, and suggests a practical mechanism for realizing the right to free access to weapons in Ukraine.

Key words: weapons, ammunition, weapons circulation, special means, storage and use of weapons, subject of self-defense, free access to weapons, free possession of weapons.

Ветуп. Головними напрямами розвитку України в XXI столітті є подальша демократизація суспільства та входження нашої держави до Європейського Союзу. Зазначене своєю чергою вимагає кардинального й невідкладного оновлення сучасної правової системи.

Україна станом на 2019 рік залишається єдиною державою в Європі, яка не має власного Закону, який би регулював обіг цивільної вогнепальної зброї. Як свідчать офіційні дані, незаконний обіг зброї в Україні зростає стрімкими темпами. Згідно з оцінками Української асоціації власників зброї на початок 2019 року в протиправному володінні українців знаходилось близько 5 млн нелегальних одиниць вогнепальної зброї [2, с. 6].

Постановка завдання. Метою статті є дослідження деяких питань нормативно-правової регламентації права на вільний доступ до вогнепальної зброї.

Результати дослідження. Правова регламентація питань у вказаній сфері в Україні розпочалася 17 червня 1992 року з прийняттям Постанови Верховної Ради України




«Про право власності на окремі види майна» та Додатку № 2 до неї, що визначає спеціальний порядок придбання громадянами окремих видів майна.

Так, спеціальний порядок набуття права власності було поширено на вогнепальну мисливську гладкоствольну й нарізну зброю, газові пістолети, револьвери та патрони до них, холодну й пневматичну зброю [5].

Офіційно процедура правового закріплення обігу зброї в Україні завершилася ще 21 серпня 1998 року. Цього дня Наказом МВС України № 622 було затверджено Інструкцію про порядок виготовлення, придбання, зберігання, обліку, перевезення та використання вогнепальної, пневматичної і холодної зброї, пристроїв вітчизняного виробництва для відстрілу патронів, споряджених гумовими чи аналогічними за своїми властивостями метальними снарядами несмертельної дії, та зазначених патронів, а також боєприпасів до зброї та вибухових матеріалів [3].

Згідно з положеннями цього нормативно-правового акта єдиними спеціальними засобами, які можна віднести до предметів самозахисту, що можуть вільно зберігатися й носитися громадянами, які досягли 18-річного віку, є аерозолі сльозоточивої та дратівливої дії [3].

Однак становлення демократичного суспільства, у якому панівними стають відносини приватної, комунальної й державної власності, вимагає також нового напряму захисту цієї власності, прав особистості, як і самої людини, їі життя, честі й гідності від злочинних посягань. Одним зі способів цього захисту є, зокрема, використання для самооборони вогнепальної зброї.

Вільне володіння зброєю - це одне з базових прав людини, якого їі може бути позбавлено лише за рішенням суду, зокрема, у разі вчинення тяжкого злочину або внаслідок втрати дієздатності. Зброя є інструментом, за допомогою якого людина може захистити себе, своїх близьких, своє майно від будь-яких протиправних посягань (з боку злочинців або узурпованої влади).

Найбільш ефективним видом зброї для самооборони є бойова короткоствольна зброя. Однак у чинному законодавстві України не передбачається механізм отримання права власності на неї з боку пересічних громадян. Не передбачається таке право й для юридичних осіб суб'єктів підприємницької діяльності, крім правоохоронних органів, охоронних структур, служби інкасації та служби перевезень цінностей Національного банку України [3]. Також згідно з Постановою Верховної Ради України від 10 листопада 1994 року № 203/94 бойовою зброєю можуть користуватися народні депутати та окремі посадові особи апарату Верховної Ради України [6].

Громадяни можуть придбати вогнепальну зброю лише у вигляді мисливської зброї (вогнепальну гладкоствольну - 321 року, нарізну мисливську - 25 років) [3]. Вважаємо за доцільне не погоджуватися з таким законодавчим вирішенням окресленого питання. У нашій державі, згідно з положеннями чинних нормативно-правових актів, повноліття настає для будь-якої особи незалежно від іï статі з 18 років. Саме вказаний вік характеризується настанням правосуб'єктності, а також є віком, з якого настає повна кримінальна відповідальність за вчинення всіх видів злочинів, передбачених Кримінальним кодексом України. Також вважаємо не зовсім доречним визначення саме 21-річного та 25-річного віку для набуття права володіння вогнепальною зброєю, оскільки до лав Збройних Сил України зазвичай призиваються особи з 18-річного віку, які, пройшовши початкове навчання, починають нести службу 3 вогнепальною зброєю (наприклад, у караулах або інших видах нарядів), причому це не мисливська рушниця й навіть не пістолет, а автоматична зброя [4].

В Україні суспільні відносини, пов'язані з обігом зброї, регулюють майже 90 нормативно-правових актів, однак, на жаль, у наведеній правовій базі відсутній головний документ - базовий регуляторний закон про зброю.

Єдиним нормативно-правовим актом, на підставі якого громадяни можуть отримати дозвіл на придбання зброї, $є$ Інструкція про порядок виготовлення, придбання, зберігання, обліку, перевезення та використання вогнепальної, пневматичної і холодної зброї, пристроїв вітчизняного виробництва для відстрілу патронів, споряджених гумовими чи аналогічними

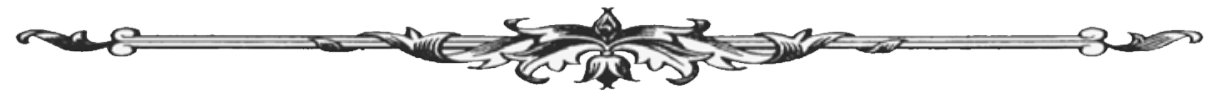


за своїми властивостями метальними снарядами несмертельної дії, та зазначених патронів, а також боєприпасів до зброї та вибухових матеріалів [3]. 3 огляду на викладене можна дійти логічного висновку, що ні закони України, ні постанови Верховної Ради України, ні укази Президента України не регулюють одну з найважливіших і найнебезпечніших сфер суспільних відносин у нашій державі, а здійснює це лише відомчий підзаконний нормативно-правовий акт, який є внутрішнім документом правоохоронного відомства.

Також недосконалість чинних нормативно-правових актів викликає низку проблемних питань у вказаній сфері та призводить до зростання кількості злочинів із протиправним застосуванням зброї. Масова свідомість живе стереотипами щодо необхідності збереження існуючого порядку набуття й використання вогнепальної зброї, оскільки є страх зростання злочинності. У наш час навіть за наявності легальної вогнепальної зброї вдома іiї вкрай важко використати $з$ метою самооборони, щоб потім не бути покараним. Засади використання зброї (насамперед для самозахисту) потрібно змінити в інтересах громадян, надавши їм можливість вільного застосування вогнепальної зброї для захисту себе, членів своєї сім’ї, інших осіб. Також потребують змін інші засади використання зброї, зокрема право на ремонт зброї, її модифікацію, транспортування.

На думку фахівців, однією з причин, яка стоїть на заваді прийняттю закону про зброю, $\epsilon$ побоювання правоохоронців щодо теоретичної можливості масового озброєння населення, які з огляду на відсутність в українців елементарної культури поводження зі зброєю часто себе виправдовують [1, с. 63-70].

Вважається, що для «розумної» реалізації права на вільний доступ до вогнепальної зброї необхідно створити ефективну систему протидії корупції як у сфері видачі дозволу на право носіння й зберігання зброї, так і в медичній сфері; створити єдиний реєстр власників зброї, у якому зберігатиметься інформація про власника зброї, результати відстрілу зброї (що унеможливить незаконне використання зареєстрованої зброї), результати медичного огляду власника зброї та час повторної перевірки стану здоров'я, інформація про те, хто видав посвідчення на право носіння й зберігання зброї, медичні довідки, інформація про місце, де особа пройшла навчання, щоб стати власником зброї.

Водночас, на нашу думку, одним із шляхів вирішення вищевказаного проблемного питання могло б стати прийняття базового регуляторного закону про обіг зброї. 4 вересня 2019 року у Верховній Раді зареєстровано Проект Закону «Про зброю» № 1222 від 02.09.2019 р., яким передбачається визначити основні принципи поводження, використання, придбання, ввезення, маркування, а також порядок отримання дозволів на зброю [7].

Висновки. Таким чином, питання права на вільний доступ до вогнепальної зброї $€$ досить дискусійним. Стан нормативно-правового регулювання обігу зброї в Україні $є$ незадовільним унаслідок відсутності законодавчого регулювання щодо ііі придбання, зберігання, носіння та застосування для самозахисту. Саме прийняття Закону України «Про зброю» забезпечить законодавче вирішення питань врегулювання обігу зброї та надасть можливість: розмежувати зброю в цивільному обороті та зброю, заборонену до цивільного обороту; запровадити чітку й зрозумілу класифікацію зброї; встановити порядок придбання, володіння, зберігання та застосування зброї; закріпити вичерпні вимоги до громадян України, які бажають отримати право на володіння зброєю; передбачити механізм тимчасового призупинення права на володіння зброєю та визначити чіткі підстави й критерії для застосування такого механізму; встановити підстави та порядок позбавлення права на володіння зброєю; створити дієву й прозору систему підготовки майбутнього власника зброї (вивчення матеріальної частини, юридичні аспекти володіння зброєю та іï застосування, отримання навичок безпечного поводження зі зброєю); визначити повноваження державних органів щодо контролю за цивільним обігом зброї; забезпечити встановлення особливого порядку судового розгляду всіх випадків, пов'язаних із застосуванням зброї з метою самозахисту, зокрема винятково судом присяжних; забезпечити право на приховане носіння зброї з метою самозахисту; передбачити процедуру внесення змін до відповідних законодавчих документів і підзаконних актів, які стосуються обігу зброї; врахувати нормативно-правові акти Євро-

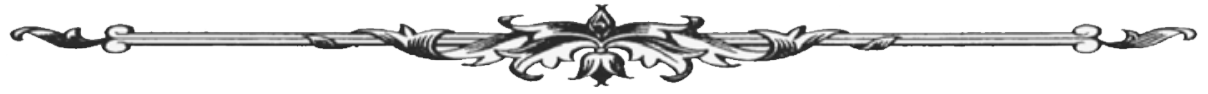


пейського Союзу; створити механізм громадського контролю за діяльністю системи ліцензування / атестації власників зброї.

\section{Список використаних джерел:}

1. Андрєєв Д.В. Проблеми кримінально-правового регулювання незаконного обігу вогнепальної зброї. Вісник ЛДУВС ім. Е.О. Дідоренка. 2017. № 2 (78) С. 63-70.

2. Дослідження незаконних потоків зброї / Публікація Small Arms Surveу за підтримки Федерального міністерства закордонних справ Німеччини. URL: http://www.smallarmssurvey. org/fileadmin/docs/T-Briefing-Papers/SAS-BP3-Ukraine-UKR.pdf.

3. Інструкція про порядок виготовлення, придбання, зберігання, обліку, перевезення та використання вогнепальної, пневматичної і холодної зброї, пристроїв вітчизняного виробництва для відстрілу патронів, споряджених гумовими чи аналогічними за своїми властивостями метальними снарядами несмертельної дії, та зазначених патронів, а також боєприпасів до зброї та вибухових матеріалів : Наказ МВС України від 21 серпня 1998 року № 622. URL: https://zakon3.rada.gov.ua/laws/show/z0637-98/page.

4. Наказ міністерства внутрішніх справ України від 13.06.2000 р. №379ДСК / 2000 / Міністерство внутрішніх справ. URL: http://zakon4.rada.gov.ua/laws/show/z0696-00.

5. Постанова Кабінету міністрів України «Про затвердження Положення про дозвільну систему» від 01.06.2012 р. № 576 / 2012. URL: http ://zakon4.rada.gov.ua/laws/show/576-92-П.

6. Постанова Президії Верховної ради України «Про забезпечення безпеки народних депутатів України та окремих посадових осіб апарату Верховної Ради України» від 10.11.1994 p. № 203/94-ПВ / 1994. URL: http ://zakon4.rada.gov.ua/laws/show/203/94-חв/ print1393444708469642.

7. Проект Закону «Про зброю» №,1222 від 02.09.2019 р. Сторінка «Законотворчість» офіиіийного веб-порталу Верховної Ради Украӥни. URL: http://w1.c1.rada.gov.ua/pls/ zweb2/webproc4_1?pf3511=12436.

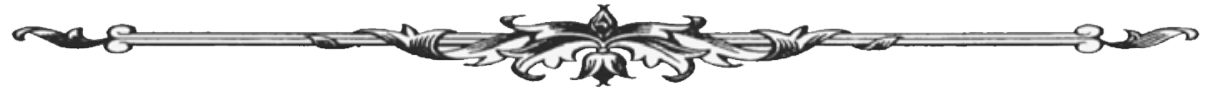

